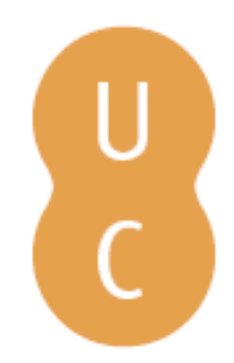

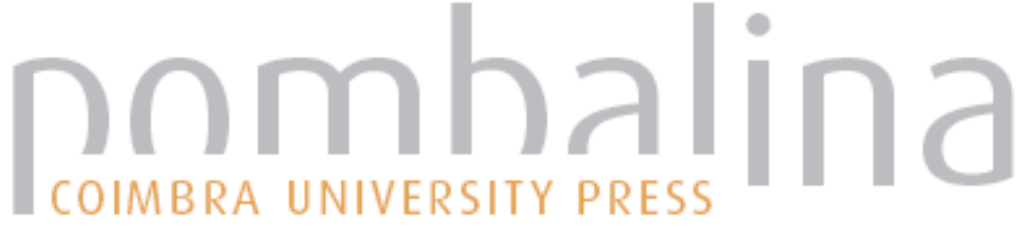

\section{Philanthropia e Philautia no Teseu de Plutarco}
Autor(es):
Fialho, M. C.
Publicado por: Centro de Estudos Clássicos e Humanísticos
URL persistente:
URI:http://hdl.handle.net/10316.2/32118
DOI:
DOl:http://dx.doi.org/10.14195/978-989-721-062-4_1

Accessed : $\quad$ 26-Apr-2023 16:22:04

A navegação consulta e descarregamento dos títulos inseridos nas Bibliotecas Digitais UC Digitalis, UC Pombalina e UC Impactum, pressupõem a aceitação plena e sem reservas dos Termos e Condições de Uso destas Bibliotecas Digitais, disponíveis em https://digitalis.uc.pt/pt-pt/termos.

Conforme exposto nos referidos Termos e Condições de Uso, o descarregamento de títulos de acesso restrito requer uma licença válida de autorização devendo o utilizador aceder ao(s) documento(s) a partir de um endereço de IP da instituição detentora da supramencionada licença.

Ao utilizador é apenas permitido o descarregamento para uso pessoal, pelo que o emprego do(s) título(s) descarregado(s) para outro fim, designadamente comercial, carece de autorização do respetivo autor ou editor da obra.

Na medida em que todas as obras da UC Digitalis se encontram protegidas pelo Código do Direito de Autor e Direitos Conexos e demais legislação aplicável, toda a cópia, parcial ou total, deste documento, nos casos em que é legalmente admitida, deverá conter ou fazer-se acompanhar por este aviso.

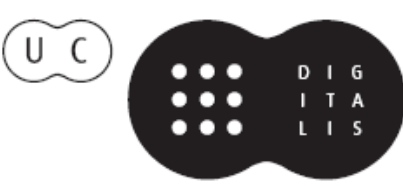


Colecção Autores Gregos e Latinos Série Ensaios

\section{Carmen Soares \\ José Ribeiro Ferreira Maria do Céu Fialho}

Ética e Paideia em Plutarco 


\section{Philanthropia e Philautia no Teseu de Plutarco}

Já por si, a biografia inscreve-se num género literário marcado por uma natureza ambígua, entre a história e a ficção novelesca. ${ }^{1}$ Da história recebe a facticidade, da ficção aquilo que Aristóteles, na Poética, ${ }^{2}$ considera ser peculiar do discurso poético - o seu grau de universalidade. Esse, possui-o a História em grau muito inferior: ao narrar o particular, segundo o Estagirita, deixa lugar à Poesia para ser "mais filosófica". Assim, a biografia adequa-se a um fim didáctico e moralizante. Recorre ao factual da vida de figuras que, potencialmente, pode ser modelado de modo a converter o destino dessas figuras em exemplum, positivo ou negativo, para o leitor, mas marcado por um processo de universalização, análogo ao da poiesis. Assim transmite, retoricamente, convicçôes de fundo sobre história, vida política, padrôes éticos, de quem escreve a biografia para o receptor pressuposto na escrita.

No caso das Vidas Paralelas de Teseu e Rómulo, estamos, à partida, perante figuras de dois fundadores - elas são, de resto, as duas únicas biografias plutarquianas de fundadores, cuja existência se funde com as origens míticas das cidades a que estão ligados: Atenas e Roma. Plutarco tem consciência disto. Por isso mesmo, o proémio destas duas Vidas possui um carácter peculiar

${ }^{1}$ H. Bauzà 2002: 183.

2 1451b) 6-7. 
que lhe advém da peculiaridade destes dois heróis, pertencentes a épocas longínquas, incertas, que escapam ao rigor da informação histórica e que se tornam terreno propício à lenda e à efabulação. Aplicando um princípio que cultiva sistematicamente, Plutarco adverte o leitor, logo à partida, da metodologia que empregou: a de submeter, até onde lhe foi possível, to mythodes ao logos: ${ }^{3}$

Seja-me então lícito submeter a lenda (to mythodes) ao processo de expurgação que a razão (logos) opera, para que aquela assuma o aspecto de História (historias opsin).

O princípio cumpre-se, na biografia de Teseu, pela aplicação metodológica, por parte de Plutarco, de múltiplos processos de racionalização ao espólio de informaçóes e versóes tradicionais diversas de que dispõe. ${ }^{4}$

${ }^{3}$ Vit. Thes. 1.5 .

${ }^{4}$ Tais processos estáo enumerados e elucidados adequadamente em C. Ampolo 1993: xii ss.: quando Plutarco se confronta com duas versóes opostas segue a mais verosímil e mais atestada (o que o próprio escritor refere em Thes. 31,2) ; essa sua atitude leva-o a silenciar episódios famosos da vida de Teseu, ou a fazer uma alusão racionalizada, como acontece com muito do que respeita à expediçấo a Creta. A mesma restrição do maravilhoso ocorre com o episódio tradicional da descida ao Hades com Pirítoo, na mesma linha da tendência os atidógrafos. Por vezes, perante várias versôes igualmente verosímeis, Plutarco limita-se a reproduzi-las. É sistemática a desconfiança nos poetas, sobretudo cómicos, e, entre os trágicos, sobretudo Eurípides. A versão dos poetas só é aceite quando confirmada por outras fontes.

Um outro traço do racionalismo de Plutarco apontado por Ampolo é a sua preferência por versóes da tradição que se liguem à instituição de um culto testemunhado pela sua sobrevivência ou pela existência de lugares onde se celebrou no passado. Nota ainda Ampolo a preocupação plutarquiana em separar a acção divina da 
A contraposição, ao longo da Vita de Teseu, de fontes documentais, ou a enumeração das que se corroboram entre si atesta que Plutarco concebeu o prólogo dentro dos moldes retóricos próprios do intróito a obras históricas. ${ }^{5}$ Eles não só se inserem numa linha de racionalismo, como se destinam a proteger o seu autor de críticas de imprecisão.

Plutarco reconhece que a distância, no tempo, em que se perde a existência de Teseu contribui para obscurecer os acontecimentos remotos. A história de acontecimentos mais próximos, todavia, debate-se, com outras dificuldades. Uma delas consiste na distorção, subjectiva e premeditada, operada pelos poetas, nomeadamente pela actividade caricatural da comédia, ${ }^{6}$ conforme reconhece na Vida de Péricles, 13. 14-16, em franca alusão aos estragos operados pela comédia. Deste modo confessa, nesse mesmo passo:

Assim se vê até que ponto é árdua e difícil para o historiador a tarefa de apurar a verdade. Todo aquele que viver depois dos acontecimentos de que se ocupar conte sempre com a acçáo veladora do tempo a ocultar-lhe o conhecimento dos factos, mas a história de feitos e vidas de contemporâneos corrompe e distorce a verdade por ódios e malquerenças ou com o intuito de agradar e lisonjear.

humana.

${ }^{5}$ C. Ampolo 1993: X-XI.

${ }^{6}$ É o que Plutarco nos diz, por exemplo, na Vida de Péricles, 13. 14-16, sobre duas vítimas desse processo: Fídias e o próprio Péricles. 
A aproximação de Teseu a Rómulo justifica-se, antes de qualquer outro motivo, pelo facto de ambas as figuras estarem associadas aos primórdios da duas cidades que se equivalem - Atenas e Roma.

Teseu é, primeiramente, designado como oikistes, fundador, e Rómulo por pater, designação que traduz uma relação visceral, bem mais profunda que aquele termo, com a cidade fundada. ${ }^{7}$

Para fazer vénia à tradição de um Teseu oikistes de Atenas, Plutarco utilizou tal recurso, introduzindo uma diferença de grau no papel de fundador, e assim preparar o terreno para realçar a distância entre a actuação do filho de Egeu e a do de Rea Sílvia através dos verbos utilizados. Teseu 'congregou' (synoikise) Atenas, enquanto Rómulo fundou, 'construiu' (ektise) Roma. ${ }^{8}$

O verbo ktizo traduz uma acção de alcance bem mais profundo que a primeira, é criação a partir do nada, lançar de fundamentos. Implica, também, uma concepção prévia de conjunto e a sua realização, com uma solidez que é garantia de estabilidade e perdurabilidade; synoikizo por seu turno, supóe reconversão, abandono do espaço ou hábitos de origem e criação de um espaço e normas comuns - Teseu terá que destruir primeiro os pritaneus locais para poder impor um pritaneu comum. ${ }^{?}$

A eficácia do seu empreendimento decorrerá, assim, da capacidade humana de fazer perdurar um pro-
7 Thes. 1. 5 .
${ }^{8}$ Ibid. 2. 2.
${ }^{9}$ Ibid. 24. 3. 
jecto, mediante o exercício continuado de um sábio equilíbrio - o que pede a intervenção decidida de um governante e a inequívoca visibilidade, na sua pessoa, dos padróes ético-políticos que pretende impor. $\mathrm{Na}$ synkrisis das biografias de ambas as figuras, Plutarco decidir-se-á, definitivamente, pela supremacia de Rómulo, que prepara desde esta primeira etapa.

A diferença entre a acção fundadora de Rómulo e a de Teseu traduzir-se-á, acaso, numa diferença de raiz entre a estabilidade da aniketos Rhome $e^{10}$ e a aventura da contingência que a democracia ateniense conheceu? Denunciará o perfil de cada uma das figuras a natureza e o modo de ser da obra executada por cada uma delas? Assim sendo, em cada uma se configuram, num processo de dimensão quase simbólica, os determinantes ético-políticos que caracterizam e diferenciam as cidades de que foram fundadores.

Ocupar-me-ei, especificamente, destas dimensôes no Teseu de Plutarco. Isto leva-me, necessariamente, a considerar o modo como Plutarco utilizou os dados da tradição sobre o fundador de Atenas, em correlação com a sua perspectiva sobre os fundamentos e qualidades da obra criada - o sinecismo e a democracia ateniense. Para tal, onde o rigor das fontes históricas falha utiliza o polígrafo de Queroneia a "memória cultural”, devidamente submetida ao filtro da racionalização, de modo a dar consistência à vida de Teseu. ${ }^{11}$

Quanto à sua origem, o mais provável é Teseu ter sido, primordialmente, um herói local do espaço rural

${ }^{10}$ Ibid. 1. 5.

${ }^{11}$ C. Ampolo 2002: 281 ss. 
do nordeste da Ática. ${ }^{12}$ Maratona e Afidnas constituem, de facto, o cenário onde se desenrolam alguns dos episódios mais antigos do mito, como a luta contra o touro, ou o ocultamento de Helena, raptada ainda criança. Da ligaçáo de Teseu a Maratona constitui ainda eco a decoração da Stoa poikile em Atenas, consoante a descreve Pausânias, 1. 15. 3. Aí se encontrava representado o herói, saindo da terra para combater os Persas em Maratona. A cena é paralela à que descreve Heródoto a propósito da tentativa persa de tomar os tesouros do santuário de Delfos. ${ }^{13}$

O nascimento mítico de Teseu em Trezena poderá, então, corresponder a uma fase posterior de expansão do conhecimento e acolhimento do herói, se tivermos em conta que, anteriormente à fixação dos Dórios na região parecem ter aí residido Iónios — naturalmente vindos do norte.

Foram descobertas em Olímpia várias trípodes de bronze, provavelmente do séc. VIII a. C., em que se pode ver representado o Minotauro. ${ }^{14}$ Todavia, a mais antiga representação da luta entre o herói e o monstro de Creta pode ser observada numa ânfora cicládica datada da primeira metade do séc. VII a. C., que se encontra no museu de Basileia.

De qualquer modo, da expansão da aceitação do herói por espaço helénico decorre uma singular genealogia e origem geográfica de carácter mítico - aquele

${ }^{12}$ H. Herther 1936: 177-239, apoiado por H. J. Walker 1995: 9 ss.

${ }^{13}$ Heródoto, 8. 38-39.

${ }^{14}$ Vide H. J. Walker 1995: 16. 
que se virá a converter no herói tutelar de Atenas por excelência, no criador do sinecismo e na figura em que se vão projectando os próprios valores de uma Atenas idealizada, é filho da união entre Egeu, o descendente da autoctonia ática, e uma mulher da casa de Pélops dórica, pois, por excelência. ${ }^{15}$ União que Plutarco explica por ter sido consumada pelo engano (hapate) ou pelo acaso de um oráculo mal compreendido. ${ }^{16}$

Trata-se, como já tive oportunidade de sublinhar, ${ }^{17}$ de uma origem 'descentrada' em relação a Atenas do herói ateniense. Ele terá que percorrer o caminho de Trezena até Atenas, até ao reconhecimento paterno e à adopção pela cidade. Defrontrará, nesse caminho, aventuras e perigos, decalcados sobre os de Héracles, conforme Plutarco reconhece.

Esse 'descentramento' afecta as próprias referências identitárias de Teseu. Teseu foi criado em segredo, segundo Plutarco, com uma falsa referência paterna a de Poséidon - para ser confrontado, no despontar da sua virilidade, com a sua verdadeira origem - a de filho de um pai humano —, através dos sinais de reconhecimento ocultos pelo rochedo que conseguiu remover. O jovem conhece, finalmente, a sua real ascendência, mas ambas as referências pesam, numa espécie

${ }^{15}$ H.J. Walker 2002, cap.2, mostra como o perfil da figura sofre, mesmo no séc. V, oscilaçóes que são fruto da projecção de concepçóes de governo e papel do governante na época, da política expansionista de Atenas no tempo de Címon, ou do questionamento das estruturas políticas da Cidade e da sua eficácia.

${ }^{16}$ Thes. 3. 5.

${ }^{17}$ M.C.Fialho 2002: 71-72. 
de paternidade dupla ou ambígua, mesmo por detrás da versáo racionalizada de Plutarco, ${ }^{18}$ quando aquele adopta, para a afirmação da sua imagem, um critério de exigência de comportamento e de excelência, imposto simultaneamente pelo facto de ser publicamente considerado como filho de um deus e pelo modo como se quer vir a apresentar perante o seu verdadeiro pai. ${ }^{19}$

O jovem escolhe o caminho para Atenas por terra e não por mar, por ser o mais difícil e por poder aí evidenciar a sua coragem. Pensa, assim, determinar o efeito do seu aparecimento público na cidade, deixando, atrás de si, um rasto de vitórias sobre perigos e ameaças.

Nota Ampolo ${ }^{20}$ que a multiplicidade de aspectos da figura de Teseu deu azo a explicaçóes diversas sobre a sua verdadeira dimensão original: entre outras a de réplica de Héracles, de herói iónico, de herói iniciático de ritos de passagem da efebia à maturidade — de que seria eco o episódio da aventura em Creta e do resgate.

Teseu em Plutarco parece-me concentrar simultaneamente traços que atestam a aglutinação de leituras e projecçóes diversas na figura, conferindo-lhe uma complexidade e contradiçóes que se tornam inalienáveis do perfil com que nos surge. Se a expedição a Creta

${ }^{18}$ Op. cit. cap. 3. Em Baquílides, nota o autor, Teseu é filho de Poséidon. Mas dessa filiação há ainda vestígios, mesmo em contextos posteriores, como no Hipólito de Eurípides. Só assim faz sentido o motivo dos três desejos cuja satisfaçáo Poséidon proporciona a Teseu.

19 Thes. 7. 2. A que se junta, ainda, a emulação com o exemplo de Héracles.

${ }^{20}$ 1993: xxvi-xxvii. 
pode, de facto, ser projecção de um ritual iniciático, centrífugo, a partir de Atenas, para depois à cidade regressar, na plena afirmação e pujança dos jovens, não me parece que o seja menos o caminho de Trezena até Atenas, do espaço da infância e da esfera materna até à presença paterna e ao reconhecimento. ${ }^{21}$ Percorre e completa esse caminho sem um nome assumido, como Plutarco assinala. Nesse caminho várias provas se póem ao jovem, que com elas se confronta e as vence, aproximando-se dos gestos de Héracles, a quem imita por adesão ao seu paradigma, para, finalmente, ostentar perante Egeu, num acto público - o banquete - a arma paterna, sinal que o levará a ser reconhecido, sem que ele necessite dar-se a conhecer.

Dos pontos de contacto entre os feitos de Héracles e os de Teseu, e da afinidade entre estas duas figuras, extrai Plutarco uma expressiva motivaçáo para a escolha do itinerário do filho de Egeu — o seu caminho para Atenas através da Megárida e não por mar.

Sobre a educação de Teseu, pouco nos diz Plutarco. Esteve aos cuidados do avô paterno, Piteu, sophotatos, mas detentor de uma sabedoria prática que, certamente, não é alheia ao engenho com que persuadiu Egeu a aproximar-se de Etra, e que teria transmitido ao neto como metis, demonstrada nos feitos em Creta e mais própria do protótipo do herói iónico. Do preceptor de Teseu, Cónidas, apenas ocorre o nome ${ }^{22}$ - não se menciona a estratégia ou a eficácia pedagógica -, talvez

${ }^{21}$ M.C.Fialho 2002: 72-73.

${ }^{22}$ Thes. 4. 
para sublinhar a influência de Piteu . Plutarco enfatiza um outro aspecto, determinante na formação de Teseu — o da força do exemplo paradigmático da acção de Héracles, transmitido em relatos que lhe suscitaram uma admiração inflamada. É esta a motivação para a escolha do caminho até Atenas: ${ }^{23}$

Do mesmo modo a admiração pelo valor de Héracles levava Teseu a sonhar de noite com os seus feitos e de dia, dominado e exaltado pelo desejo de emulaçáo (zelos), pensava em praticar feitos semelhantes.

A aproximação de Teseu à figura de Héracles é modelada pelo erudito de Queroneia à luz das suas convicçôes acerca do papel educativo do exemplo das acçôes ilustres, operado sobre a alma humana, e a que alude com frequência nos seus escritos de filosofia moral.

Plutarco, ao sublinhar a força educativa do exemplo de Héracles com o caso prático do jovem Teseu, chama, por sua vez, a atenção para o potencial educativo e formativo das próprias Biografias que escreve. Ao exemplo como factor dinâmico da paideia dedica o escritor um dos mais belos e expressivos passos das Vitae - a abertura da biografia de Péricles - recorrendo a uma comparação muito do seu gusto, a do efeito de estímulos visuais sobre a própria visão: ${ }^{24}$

Pois tal como a cor mais benéfica para os olhos é aquela cujo brilho e doçura estimulam e tonificam a visão, assim

${ }^{23}$ Thes. 6. 9.

${ }^{24}$ 1. 3-4. 
mesmo se torna necessário encaminhar o pensamento para a contemplação de espectáculos que, por efeito do prazer que suscitam, conduzem aquele ao bem que lhe é intrínseco.

Tais espectáculos consistem nas acçóes nascidas da virtude e despertam, nos homens que os observam, um sentimento de emulação e o desejo de os imitar.

Convertidas platonicamente num equivalente ao bem, que se impóe, pela sua beleza, e fascina a alma humana a contemplá-lo, tornando-se, assim, motor da acção humana, as obras nascidas da arete actuam, suscitando em quem delas toma conhecimento, um natural anseio de imitação (mimesis) através do sentimento de emulação e desejo de as igualar (zelos kai prothymia). ${ }^{25}$

Na mesma Vita, em 2. 1-2, Plutarco acrescenta:

Não acontece necessariamente, se uma obra nos encanta pela sua beleza, que o seu autor seja digno de admiração. Por isso, não há vantagem em contemplar tais obras que não provocam a emulação nem o arrebatamento que suscita o desejo e o afá de as imitar. A virtude, em contrapartida, pelas acçóes que inspira, dispóe claramente à admiração pelos feitos e à simultânea emulação com os seus autores.

Identificam-se, nestas palavras, ecos da velha questão platónica da República: a beleza das obras de arte, em si, pode encantar e envolver os sentidos, mas tal

${ }^{25}$ Quanto ao papel da emulação (zelos) como um dos componentes essenciais na formação moral das figuras das Vitae de Plutarco, e sobre o lugar que ocupa a referência a zelos nprogressáo peculiar do esquema das biografias, vide A. Pérez Jiménez 1985: 100-105. 
envolvimento não acarreta consigo elevação da alma essa só é motivada por obras que apelem para o aperfeiçoamento ético através de uma emulação suscitada pelo apelo e força de um paradigm. É o apelo à identificação, suscitado pela beleza da própria virtude, que tem validade ética e capacidade de orientar uma paideia eficaz. Para o polígrafo de Queroneia essa atracção das obras da arete exercida sobre a alma em formação pressupóe nesta última uma predisposição que é também arete inata e que aspira, ao receber o estímulo de uma acção modelar que se impóe como espectáculo, a elevar-se à superioridade desta e com esta se medir, numa saudável emulação, traduzida em actos.

Ora os perigos que Teseu defrontou no percurso até Atenas, os malfeitores punidos e exterminados traduzem o efeito actuante do exemplo pedagógico de Héracles sobre um jovem cuja predisposição para a philantropia e para a megalophrosyne se realiza em actos que têm como objectivo exercer e manifestar a coragem e libertar aos viandantes os caminhos. Essa série de aventuras aparece, assim, no relato de Plutarco, integrada no todo de um percurso conseguido, coeso, sem dispersão, até à figura paterna. Nota Ampolo o cuidado posto por Plutarco no relato da juventude dos biografados, para aí apontar o potencial de características que se hão-de tornar dominantes nas suas existências. ${ }^{26}$ Todavia, nesses mesmos feitos se denuncia já, discretamente, num relato de estupro diluído - o de Periguna - a presença de

${ }^{26}$ 2002: 282-285. 
impulsos que Teseu não controlará. A força do impulso erótico e do irresistível desejo de saciar o prazer hão-de tomar, progressivamente, conta da conduta de Teseu até lhe desestruturar os seus projectos de acção política, causando a sua ruína. Reconheçamos que esse elemento está também presente no mito de Héracles e foi causa, para este, de fatais dissabores.

Pode, antecipadamente, concluir-se que Teseu não soube apropriar-se criticamente do paradigma pedagógico que tanto o fascinou e de que se quis aproximar. Estaria, no espírito de Plutarco, presente a ideia de fazer perceber ao seu leitor a necessidade de apropriação crítica dos exemplos das Vitae? De que com os excessos dos heróis, ainda que corajosos e nobres, se aprende também, pela negativa? É bem provável que sim.

Ainda assim, cultivando a força do exemplo, Teseu, num impulso de generosidade, oferece-se para integrar o grupo de reféns destinado a Minos. O que suscita, por seu turno, a admiração dos atenienses pela sua grandeza de espírito (phronema) e pela sua devoção ao povo (demotikon): ${ }^{27}$

Estas queixas afligiam Teseu, que entendeu ser justo não se alhear, mas antes tomar parte na sorte dos seus concidadãos, pelo que se foi oferecer espontaneamente, antes do sorteio. Aos demais pareeu admirável esta grandeza de espírito e louvaram a sua devoçáo ao povo...

Todavia, ao oikistes fundador de ritos, libertador de caminhos e da juventude ateniense, falta a capacidade

${ }^{27} 17.2$. 
de exercício — askesis — da razão sobre a parte irracional da alma. ${ }^{28}$ Mesmo na grandeza de espírito que o leva a arrostar com o perigo percebe-se o componente impulsivo que o força a ceder a um prazer sob a forma de eros descontrolado - o que se converterá na causa da sua ruína. Como foi dito, já nessa espécie de caminho iniciático de Trezena até Atenas se denuncia tal fraqueza. Plutarco assinala em mais de uma dezena as mulheres tomadas à força ou seduzidas e abandonadas por Teseu até ao clímax da sua hybris de hedone, atingido com o rapto de Helena ainda criança: ${ }^{29}$

Este comportamento faz suspeitar que ele agia por violência e por prazer .

Quer isto dizer que, para o caso de Teseu, as qualidades promissoras reveladas na juventude vão entrar em tensão progressiva com a força da paixão, que ele não há-de ser capaz de dominar. Por essa via será vítima da sua própria desordem de alma e porá em risco a boa ordem da cidade que governa. Não é a generosidade, filha de um impulso, que deve guiar a acção de quem governa, mas a devoção ao bem comum. Mesmo que o impulso tenha como consequência, uma vez, a libertação de alguém (os jovens enviados para Creta), enquanto impulso, ainda que generoso, não deixa de representar uma forma de prisão do homem a forças

${ }^{28}$ Sobre a askesis como uma das principais condiçóes para alcançar a virtude, veja-se A. Pérez Jiménez 1985: 35 ss.

${ }^{29}$ Rom. 35. 2. 
irracionais, do mesmo modo que eros. No primeiro caso trata-se de uma forma de philautia com repercussóes benéficas. No segundo caso, a philautia terá consequências desastrosas. É frágil a fronteira entre auto-estima e egoismo quando o homem não alcança a consistência ética dada por uma paideia a que não é alheio o esforço, o olhar crítico sobre os paradigmas que se oferecem e a vigilância sobre si mesmo.

Se, para Plutarco, os males humanos não podem, frequentemente, ser imputáveis aos deuses, mas ao acaso e à acção humana que, combinada com a tyche, pode levar o homem ao sofrimento, ${ }^{30}$ o filósofo entendia, certamente, o destino de Teseu como ilustração deste princípio - conforme o atesta a própria synkrisis. ${ }^{31}$ Ele náo deixa de ver no rapto de Helena - o maior dos desmandos cometidos por Teseu - uma das causas do malestar e da sedição (stasis) do povo ateniense contra o seu governante. ${ }^{32}$

O criador do sinecismo não soube, por uma falha estrutural do seu carácter, conferir estabilidade e solidez a um vínculo social que é a base da estrutura de uma comunidade organizada - a uniáo conjugal. Rómulo, fundador e construtor de Roma, usou-a, em contrapartida, como pedra angular da sociedade romana e como um dos pilares da conciliaçáo e aliança política que fortalece o estado e que deu azo à prosperidade de Roma. ${ }^{33}$

${ }^{30}$ Vide A. Pérez Jiménez 1973: 101-110.

${ }^{31}$ Rom. 32. 1.

${ }^{32}$ Thes. 31 ss.

${ }^{33}$ Rom. 35. 2-3. Para uma melhor compreensão da importância do texto no contexto da synkrisis da bigrafia de Teseu e de Rómulo, 
Mais ainda: como homem de acção impulsiva, o criador do sinecismo não soube desenvolver, pelo exercício e pela pertinácia, as qualidades racionais do bom governante, mesmo como mero guardiāo das leis, de modo a poder dar coesão à nova configuração da Cidade. O prazer, sob a forma de eros, agiu como factor de dispersão e força centrífuga que o desenraizou de Atenas. Prometendo à cidade a isoimoiria, divide-a, na prática, em classes sem direitos equivalentes, ${ }^{34}$ prometendo-lhe uma democracia de que ele seria mero chefe na guerra e guardiāo das leis (24. 2), afasta-se da cidade e deixa que o povo singre sem timoneiro, ao sabor de demagogos e dos seus próprios vícios latentes, deixa que as várias classes se digladiem entre si. ${ }^{35}$ Após ter dado livre curso às paixóes, numa alma desordenada, que encontra Teseu, de regresso à cidade? ${ }^{36}$

Quando quis tomar de novo conta do poder, como anteriormente, e assumir a chefia do governo, caiu no meio de revoltas e desordens. Descobriu que quantos o odiavam antes de partir tinham acrescentado ao ódio o facto de já não terem medo dele.

Deixando, certamente, passar ecos da concepção platónica de uma República que tem em si a imagem da própria alma, Plutarco sublinha a similaridade do percurso de Atenas, progressivamente tomada pela paixão do mando e pela desordem, com o do seu fundador.

em que se situa, veja-se H. Erbse 1956: 398-424.

${ }^{34} 25.1-2$.

3532.1 ss.

3635.4 . 
O papel do governante ideal, para Plutarco, identificado com o do monarca que age com a mesma intervenção ordenadora com que a razão opera na alma, está longe desta figura excepcional, mas marcada por contradiçóes, por falhas estruturais que determinarão o seu exílio e a sua morte, despenhando-se do alto de um rochedo.

A sua morte pode ser tida como a paradigmática imagem do desenlace do percurso existencial daquele que ao mais alto subiu para se despenhar no abismo perspectiva antropológica táo cara à poesia grega arcaica, à tragédia clássica, às Histórias de Heródoto. Quer isto dizer que Plutarco, apesar de desprezar os relatos dos poetas, póe-nos perante um itinerário quase trágico de uma figura heróica, com a diferença de faltar à figura do fundador de Atenas o necessário reconhecimento do limite e do erro, característico dos protagonistas trágicos.

Em conclusão, parece haver, entre as virtudes e fraquezas de Teseu e as virtudes e fraquezas da sua própria cidade, uma estreita simbiose, uma correspondência que Plutarco teria esboçado conscientemente, de modo a que os vícios e a magnitude do criador do sinecismo assumam uma dimensão arcaica, no sentido etimológico do termo. Na praxis de Teseu transparece, em meu entender, a etiologia das próprias fissuras e contradiçôes da democracia ateniense e no destino daquele pode ler-se a antecipação do destino de uma cidade que conheceu um excepcional esplendor político e cultural, marcado pela 
philantropia e megalophrosyne, mas sem a askesis que lhe permitisse refrear a cupidez de poder e lucro.

É que essa askesis opera através da intervenção sábia e decidida do governante, num sistema de monarquia - governante atento ao seu próprio equilíbrio moral como fonte de competência para salvaguardar a harmonia do estado que governa. ${ }^{37}$

Difícil é esse equilíbrio, solicitando atenção constante, e esbatida a fronteira que o separa da degenerescência em democracia ou em tirania. Ambas são, para Plutarco, formas de governo adulteradas, de sinal contrário, mas nascidas da mesma fonte - a perda da justa relação do governante com o poder que exerce, decorrente ou da philantropia ou da philantia $^{38}$ e que o irá converter em demagogo ou em déspota. Assim o salienta na synkrisis: ${ }^{39}$

Pese embora terem nascido ambos com vocação para governar, nenhum deles soube conservar a conduta política de um rei. Dela se afastaram, porquanto um a converteu em democracia e o outro em tirania, vindo a cair no mesmo erro por sentimentos contrários. É que um governante deve salvaguardar, antes de tudo, a própria governação. E salvaguarda-a tanto quando se abstém do que lhe não convém

${ }^{37}$ A. Pérez Jiménez 2004: 49-64 formula a hipótese, com exemplos ilustrativos, de as Vitae e a respectiva synkrisis final, incluindo a de Teseu e de Rómulo, fornecerem deliberadamente modelos de leitura, de aplicação tácita, para a história de Roma do séc. I p. C. (2004)

${ }^{38}$ Rom. 31.

39 Sobre a função da synkrisis nas Biografias vide Pelling (1986) 83 ss. , Th.Duff 1999, caps. 8-9. 
como quando procura o que lhe é conveniente. Mas aquele que afrouxa ou endurece a sua autoridade deixa de ser um rei e um dirigente para se converter num demagogo ou num déspota que inspira ódio ou desprezo nos homens a quem governa. O primeiro dos vícios em causa parece decorrer da brandura e da humanidade, o segundo do egoismo e da dureza.

Podemos, assim, dizer que o papel da philautia como limitação crescente e não ultrapassada em relação às qualidades morais de philantropia e megalophrosyne de Teseu é retomado na synkrisis final de modo a revelar-se como uma tensão que afecta a própria governação e que se contagia à cidade. Talvez Plutarco pretenda assinalar que o destino da poderosa democracia de uma Atenas que foi um centro de cultura e pensamento fulgurantes se deveu à philautia do seu poder hegemónico e da luta pela preponderância no interior da cidade: como atrás disse, entre auto-estima e egoismo, mesmo falando de uma comunidade, caso a solidez de uma formação ético-política esteja ausente, a fronteira é débil. 